\title{
Relationship between water temperature and phytoplankton communities in Ba Lai river, Viet Nam
}

\author{
Tran Thi Hoang Yen ${ }^{1}$, Dinh Le Mai Phuong ${ }^{2}$, Tran Thanh Thai ${ }^{1}$, Nguyen Thi My Yen ${ }^{1}$, Ngo Xuan Quang ${ }^{1,2}$, \\ Pham Thanh Luu ${ }^{1,2}{ }^{*}$
}

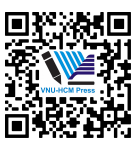

Use your smartphone to scan this QR code and download this article

${ }^{1}$ Institute of Tropical Biology (ITB), Vietnam Academy of Science and Technology (VAST), 85 Tran Quoc Toan Street, District 3, Ho Chi Minh City, Vietnam

${ }^{2}$ Graduate University of Science and Technology (GUST), Vietnam Academy of Science and Technology (VAST), 18 Hoang Quoc Viet, Hanoi, Vietnam

Correspondence

Pham Thanh Luu, Institute of Tropical Biology (ITB), Vietnam Academy of Science and Technology (VAST), 85 Tran Quoc Toan Street, District 3, Ho Chi Minh City, Vietnam

Graduate University of Science and Technology (GUST), Vietnam Academy of Science and Technology (VAST), 18 Hoang Quoc Viet, Hanoi, Vietnam

Email: thanhluupham@gmail.com

History

- Received: 2020-02-11

- Accepted: 2020-06-15

- Published: 2020-06-30

DOI : 10.32508/stdj.v23i2.1755

\section{Check for updates}

\section{Copyright}

(c) VNU-HCM Press. This is an openaccess article distributed under the terms of the Creative Commons Attribution 4.0 International license.

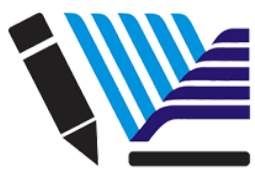

VNU-HCM Press

\begin{abstract}
Introduction: Phytoplankton which can affect higher trophic levels play a pivotal role as primary producers. Phytoplankton structure and diversity may, besides other factors, be controlled by the changing of water temperatures. Hence, the present study aimed to determine some relationship between phytoplankton assemblage and water temperature in Ba Lai River, Vietnam. Methods: In this research, sample data along the Ba Lai Estuary during two surveys were carried out in rainy season (September, 2017) and in dry season (March, 2018), and analyzed by Spearman's correlation and Linear regression analysis to find the correlations. Results: The results showed that the temperature of surface water in Ba Lai River was quite stable spatially. A total of 128 species belonging to 5 groups- namely cyanobacteria, diatoms, green algae, euglenids and dinoflagellates- were recorded in which diatoms were clearly dominant. Additionally, multiple stepwise linear regression revealed that phytoplankton assemblage correlated significantly with the temperature of surface water. The water temperature had a significant positive correlation with chlorophyll-a concentration but was negatively correlated with Margalef's diversity index in the rainy season. Moreover, the significant negative association of water temperature with biomass of phytoplankton and biomass of diatoms, which was principal in species number, were determined in the dry season. Conclusion: This study investigated the phytoplankton communities and found their correlation with environment in the area, and demonstrated advantages of phytoplankton which warrant their further research.
\end{abstract}

Key words: Linear regression analysis, Phytoplankton assemblage, Spearman's correlation analysis, the water temperature

\section{INTRODUCTION}

Phytoplankton contribute to nearly half of the annual global primary production and are major drivers of biogeochemical cycling, thereby sustaining the food webs of most ecosystems; thus, they have garnered increased attention in research ${ }^{1}$. Phytoplankton are useful indicators of water quality because their spatial and temporal patterns reflect both short-and longterm environmental changes ${ }^{2}$. Therefore, changes in phytoplankton community structure and diversity can be evaluated to understand impact of environmental changes on ecosystems ${ }^{3}$.

The favorable environmental parameters (e.g. $\mathrm{pH}$, temperature, salinity, dissolved oxygen, and nutrients) in estuarine and coastal waters have been reported to affect and link with the diversity, distribution, abundance, and composition of phytoplankton ${ }^{4,5}$. Temperature is among the major factor to influence phytoplankton growth rates, nutrient stoichiometry, and spatial and temporal distribution in freshwater systems. The alteration of seasonal temperature and increasing water temperatures, in addition to other parameters, may control phytoplankton growth and diversity. Additionally, biodiversity is decreasing at a rapid rate and this decrease is further accelerated by artificial climate change and associated rising temperatures on a global scale ${ }^{6}$. An increasing number of studies have focused on how phytoplankton primary productivity and species composition are influenced by water temperature, triggered by an interest to understand how global warming affects ecosystem processes and properties ${ }^{7}$. The combined effects of temperature and diversity on phytoplankton growth have been emphasized in recent study of Schabhüttl et al. $(2013)^{6}$. In this research, high temperature had a negative effect on phytoplankton diversity, in that a temperature-dependent decrease in diversity was most obvious in communities adapted to cooler base temperatures. Moreover, green algae and diatoms have shown a trend to perform better at lower temperatures, while cyanobacteria have shown a stronger relationship with increasing temperatures in mixed communities ${ }^{6}$. Besides, the main objective of the study in Tagus Estuary (Portugal) was to identify the key environmental factors affecting phytoplankton structure. BIOENV analysis revealed that in 
study period, the water temperature and other factors were the variables that had the strongest correlations with the phytoplankton community along the Tagus Estuary and best explained the phytoplankton spatial pattern ${ }^{8}$. The study in the Yangtze River (China) observed that water temperature, nutrient concentrations and light availability were the driving factors that determine phytoplankton dynamics ${ }^{9}$.

$\mathrm{Ba}$ Lai River is a river in the Mekong Delta region which flows through Ben Tre Province. It is a direct tributary of Tien River and the natural boundary between Phu Duc and Tan Phu Communes. At the beginning of the 20th century, the river became alluvial, narrow and shallow. Nowadays, the water source of Ba Lai River comes mainly from the My Tho River. Ba Lai River has also begun to diminish while Ba Lai Estuary is filling with sediment and becoming blocked. In 2002, in the Ba Lai Estuary, the construction of the Ba Lai dam which functions to prevent salinity, create a fresh source of water, and supply water for the districts of Binh Dai, Ba Tri, Giong Trom, Chau Thanh in Ben Tre Town, has been considered as an environmental failure for the originally connected estuarine and river ecosystems ${ }^{10}$. Several studies have warned that the Ba Lai dam could result in a high disturbance and deposition of this river ${ }^{11}$. According to a recent study of phytoplankton community structure in Ba Lai River, it was revealed that the water quality had shown signs of serious deterioration through biological indicators and there were other evidence which indicated that the Ba Lai dam negatively affected the phytoplankton communities. The phytoplankton distribution was influenced by the environmental parameters ${ }^{12}$.

The main objectives of this paper were to characterize the influence of water temperature, one of the main environmental factors, on controlling the distribution pattern of phytoplankton communities and diversity in the Ba Lai River, therefore contributing to the assessment and monitoring of aquatic environments.

\section{MATERIALS AND METHODS}

\section{Study area and field sampling}

Two surveys were conducted at 10 sites (represented by nomenclature BL1 to BL10) in the Ba Lai River in March of 2018 (dry season) and September of 2017 (rainy season) (Table 1, Figure 1). The water temperature was collected from the surface and measured in situ by using a multi-parameter system (Hach 156, Company, USA).

Planktonic diatom samples were collected from the surface waters by towing a conical net made of bolting silk with $25 \mu \mathrm{m}$ mesh size. Subsequently, samples

\begin{tabular}{|c|c|c|}
\hline \multirow[t]{2}{*}{ Sites } & \multicolumn{2}{|c|}{ Sampling coordinates } \\
\hline & Latitude & Longitude \\
\hline BL1 & $10^{\circ} 17^{\prime} 29.8^{\prime \prime} \mathrm{N}$ & $106^{\circ} 12^{\prime} 40.2^{\prime \prime} \mathrm{E}$ \\
\hline BL2 & $10^{\circ} 18^{\prime} 43.7^{\prime \prime} \mathrm{N}$ & $106^{\circ} 17^{\prime} 38.5^{\prime \prime} \mathrm{E}$ \\
\hline BL3 & $10^{\circ} 17^{\prime} 38.8^{\prime \prime} \mathrm{N}$ & $106^{\circ} 21^{\prime} 22.0^{\prime \prime} \mathrm{E}$ \\
\hline BL4 & $10^{\circ} 16^{\prime} 10.8^{\prime \prime} \mathrm{N}$ & $106^{\circ} 26^{\prime} 24.5^{\prime \prime} \mathrm{E}$ \\
\hline BL5 & $10^{\circ} 12^{\prime} 30.6^{\prime \prime} \mathrm{N}$ & $106^{\circ} 32^{\prime} 6.48^{\prime \prime} \mathrm{E}$ \\
\hline BL6 & $10^{\circ} 11^{\prime} 05.8^{\prime \prime} \mathrm{N}$ & $106^{\circ} 34^{\prime} 35.8^{\prime \prime} \mathrm{E}$ \\
\hline BL7 & $10^{\circ} 10^{\prime} 17.7^{\prime \prime} \mathrm{N}$ & $106^{\circ} 36^{\prime} 48.6^{\prime \prime} \mathrm{E}$ \\
\hline BL8 & $10^{\circ} 08^{\prime} 44.9^{\prime \prime} \mathrm{N}$ & $106^{\circ} 38^{\prime} 01.1^{\prime \prime} \mathrm{E}$ \\
\hline BL9 & $10^{\circ} 08^{\prime} 17.1 " \mathrm{~N}$ & $106^{\circ} 38^{\prime} 35.6^{\prime \prime} \mathrm{E}$ \\
\hline BL10 & $10^{\circ} 02^{\prime} 38.5^{\prime \prime} \mathrm{N}$ & $106^{\circ} 41^{\prime} 03.7^{\prime \prime} \mathrm{E}$ \\
\hline
\end{tabular}

were kept in $150 \mathrm{ml}$ plastic bottles, preserved in $4 \%$ neutralized formalin and used for qualitative analysis; chlorophyll-a analysis samples were collected by used plastic cans (each with a capacity of $2 \mathrm{~L}$ of surface water), and preserved in $4 \%$ neutralized formalin for qualitative analysis ${ }^{13}$.

\section{Planktonic diatom identification and chlorophyll-a analysis}

Samples were examined with an inverted microscope (CK40, Olympus, Japan) at $200 \times$ or $400 \times$ magnification. Identification was based on morphology per examples from the literature ${ }^{14-16}$. The classification of phytoplankton into taxonomic groups and verification of currently accepted taxonomic names followed AlgaeBase ${ }^{17}$. At least 500 cells were counted under Sedgewick counting technique, a method by Sournia (1978) to determine abundance $^{18}$. The biomass of cells was calculated based on geometrical formulas according to Sun and Liu (2003) ${ }^{19}$. Biovolume was calculated based on geometrical cells or colony volumes and subsequently converted to biomass (wet weight) by assuming a specific gravity of $1 \mathrm{mg} / \mathrm{mm}^{3}$ (Wetzel and Likens, 2013) ${ }^{20}$.

In order to analyze chlorophyll-a concentration, about 100-300 mL samples were filtered through GF/C filter paper. The filter was subsequently frozen until sample processing. Chlorophyll-a was dissociated with $90 \%$ acetone solution overnight at room temperature and in the dark. The samples were centrifuged at $400 \mathrm{rpm}$ for 20 minutes to discard scum. Chlorophyll-a in the extract solution was analyzed by an UV-DR-500 spectrophotometer (Hach, USA). 


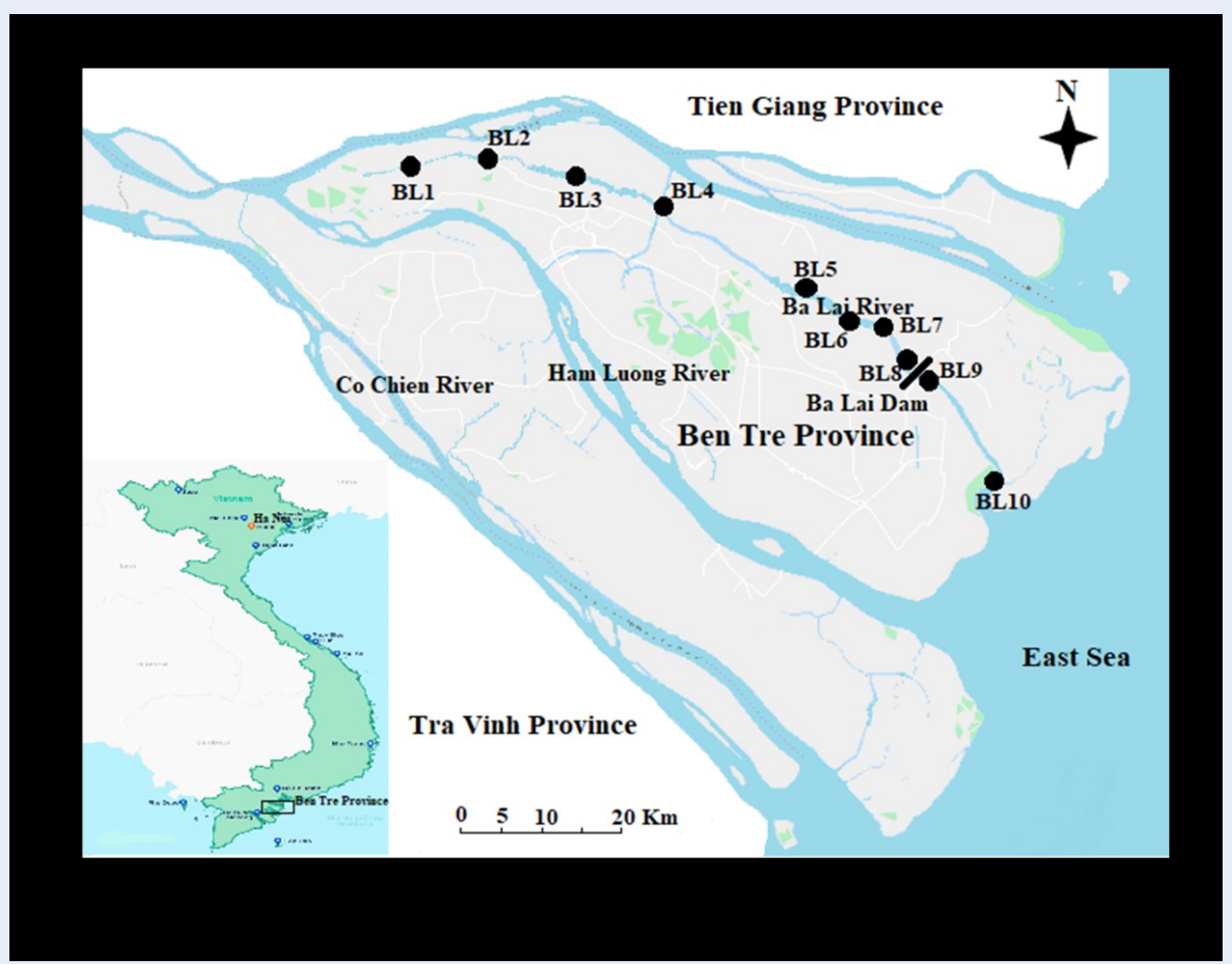

Figure 1: Sampling stations in Ba Lai river, Ben Tre province.

\section{Data analysis}

The phytoplankton community structure of species richness was assessed by Margalef's index (d) and Pielou's evenness index (J') which were used to characterize the phytoplankton community at each site. These metrics were calculated by using the PRIMER VI analytical package developed by Plymouth Marine Laboratory (U.K.).

One-way analysis of variance (ANOVA) was used to test the significance of the differences among the sites based on the water temperature and the phytoplankton species structure metrics. The analysis was completed, using Tukey's HSD test significant difference. The correlations between the water temperature and the phytoplankton community structure and diversity were determined by Spearman's correlation analysis method, and then linear regression analysis was performed. All variables were log-transformed $(\log +1)$ to normalize their distributions before analysis. Statistical calculations were performed using Statgraphic centurion XV.

\section{RESULTS}

\section{The water temperature and chlorophyll-a concentration}

Temperature is important because it has a massive effect on determining what organisms can survive in a body of water and also directly affects the rate of photosynthesis and sensitivity of organisms' toxic wastes $^{21}$. The results showed that temperature of surface water in the Ba Lai River was quite stable spatially. It varied between a minimum rate of $27.60^{\circ} \mathrm{C}$ in the dry season and a maximum rate of $33.95^{\circ} \mathrm{C}$ in the rainy season (Figure 2). One-way ANOVA was performed and showed that no significant difference in the surface water temperature was detected between the two seasons $(p>0.05)$. The temperature of the survey in Ba Lai River was relatively stable and there were not so large fluctuations between the sample sites and between the two surveys. Ba Lai River is located in the tropical region which has a similar water temperature as some other bodies of water in Southern Viet Nam (range of $\left.28-32^{\circ} \mathrm{C}\right)^{22}$. The average water temperature of approximately $30^{\circ} \mathrm{C}$ reflects positive conditions for development of phytoplankton ${ }^{23}$.

Chlorophyll-a concentration varied between 0-58.05 $\mu \mathrm{g} / \mathrm{L}$ with the minimum and maximum concentrations occurring in the dry season (Figure 3); these 


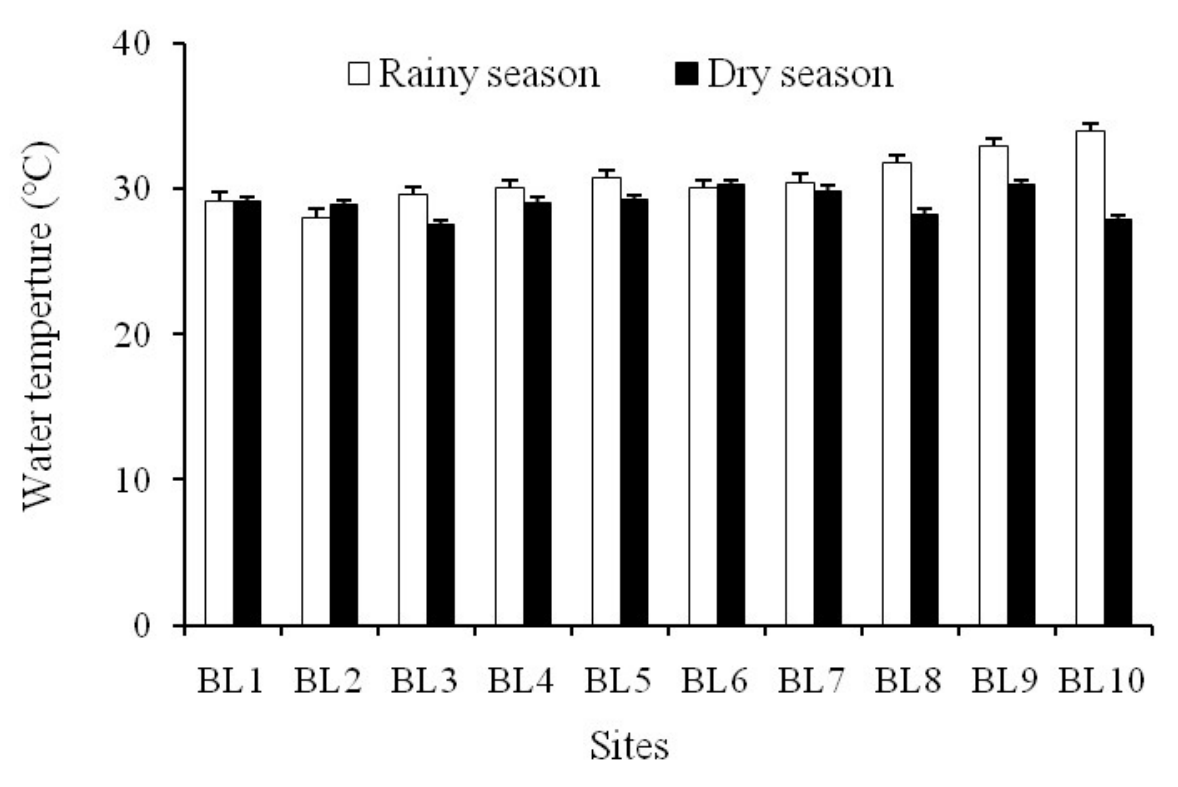

Figure 2: The water temperature from sampling sites in dry and rainy seasons.

concentrations are higher in some seaward areas than in the inner zone of the Ba Lai River estuary. There was a significant increase from the upstream sections to the downstream river sections in both surveyed seasons. Generally, chlorophyll-a concentration was high at stations BL7, BL8, and BL9; it was highest at BL9 station (which was below the Ba Lai dam). Meanwhile, BL3 station had the lowest chlorophyll-a concentration. Phytoplankton need light and nutrients to develop. Since the water environment of Ba Lai River had high alluvial content, turbidity and strong disturbance, these factors prevented light from entering the water environment, leading to poor growth and development of phytoplankton, and resulting in low chlorophyll-a content in that area. BL3 station had high turbidity and total suspended solids (TSS) values that led to low concentration of chlorophyll-a.

\section{Phytoplankton composition and abun- dance}

\section{Species composition of phytoplankton}

From the two surveys, a total of 128 phytoplankton species, belonging to 5 phyla and 76 genera were identified from the Ba Lai River (Figure 4). The phytoplankton species were predominantly Bacillariophyceae (69 species, gaining $53.91 \%$ of total species number), followed by Chlorophyceae (25 species, $19.53 \%)$, Cyanophyceae (19 species, $14.84 \%)$, Dinophyceae (8 species, 6.25\%), and Euglenophyceae (7 species, 5.47\%) (Figure 4C). The number of Bacillariophyceae was most dominant in both seasons which could be related to the fact that diatoms could thrive well in varying environmental changes, while the number of Euglenophyceae and Dinophyceae were lower than the other phylas. The species number of phytoplankton in the rainy season was higher than that in the dry season. Particularly, the number of Dinophyceae was only recorded in the lower part of the Ba Lai dam in the dry season, while the number of Chlorophyceae and Cyanophyceae often appeared at sites near the upper part of the dam in the rainy season. This corresponded to the study conducted on the Ba Lai River by Pham et al. (2017) ${ }^{12}$.

\section{Phytoplankton abundance and biomass}

Phytoplankton densities ranged from 301-1185 × $10^{3} \mathrm{cells} / \mathrm{L}$ in the rainy season and from $303-683 \times$ $10^{3}$ cells/L in the dry one. The maximum abundance (up to $1185 \times 10^{3}$ cells/L) occurred at BL9 station in the rainy season, whereas the minimum density (301 $\times 10^{3}$ cells/L) was recorded at BL5 station in the rainy season (Figure 5). The BL9 station had highest density because of the increasing abundance of several cyanobacterial species, including Anabaena smithii, Planktolyngbya limnetica and Oscillatoria limosa, accompanied by the decreasing abundance of marine diatoms. The phytoplankton usually distributed according to the rule that the freshwater species (such as 


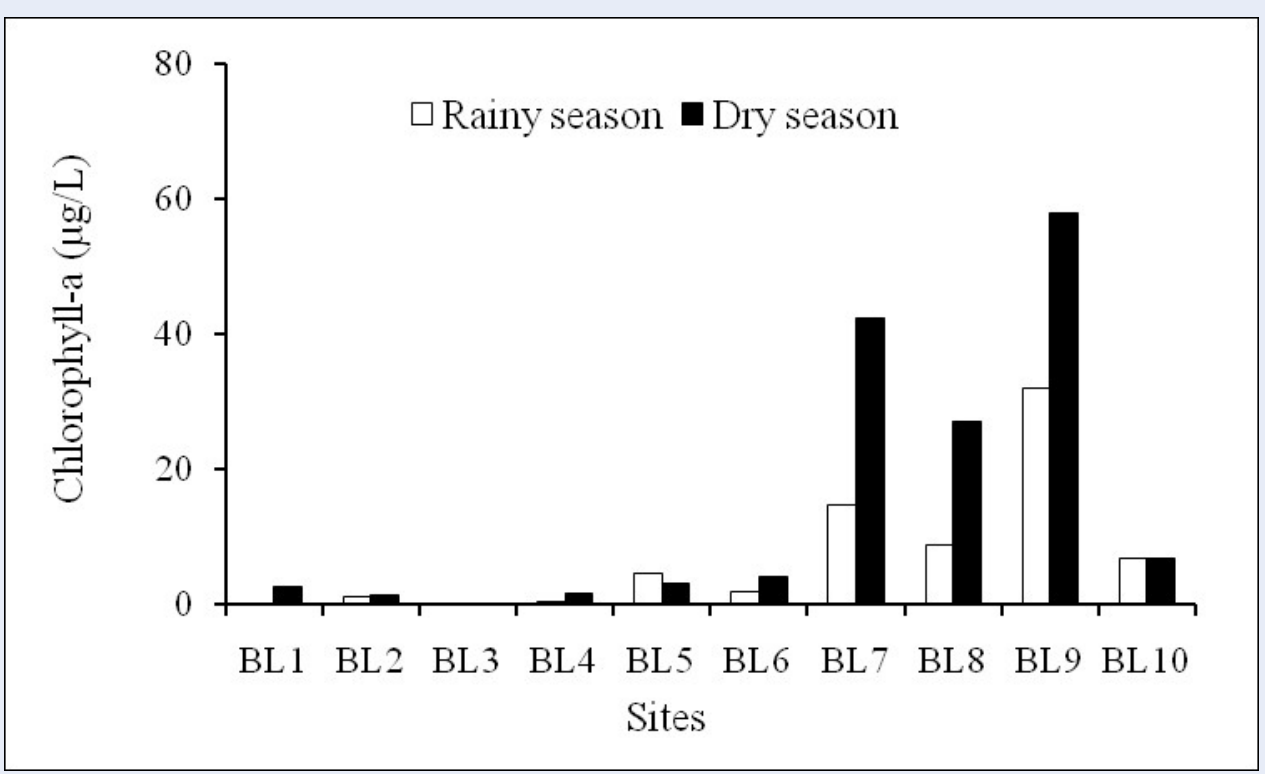

Figure 3: Chlorophyll-a concentration in two seasons.
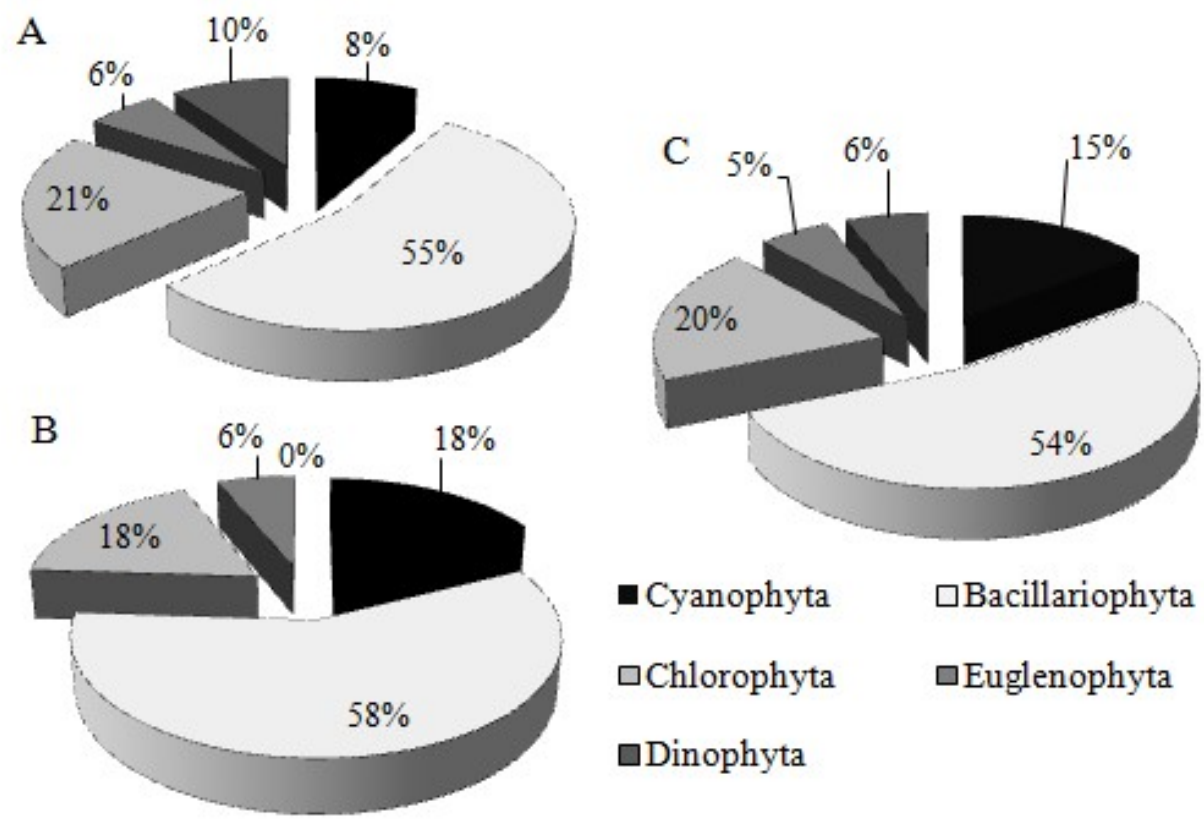

- Cyanophyta $\quad \square$ Bacillariophyta

$\square$ Chlorophyta $\quad \square$ Euglenophyta

口inophyta

Figure 4: The seasonal distributions of phytoplankton composition in Ba Lai River in dry season (A), rainy season (B), and both seasons (C). 
cyanobacteria and green algae) were more observed at upper stations and decreased at lower stations, while the phytoplankton communities were more characterized by marine diatoms in downstream stations. However, at the sites near the Ba Lai dam, the distribution of phytoplankton communities was disturbing. At stations BL8 and BL9 (which are considered downstream stations), the abundance of cyanobacteria and green algae were higher than marine diatoms. Besides, cyanobacteria has an advantageous characteristic which is optimal growth at higher temperatures, whereas diatoms grow better at relatively lower temperatures 22,24 . The phytoplankton species which were predominant in quantitative samples at some sites of the Ba Lai River were as follows: Anabaena smithii, Dolichospermum affine, Planktolyngbya limnetica, Coscinodiscus rothii, Coscinodiscus subtilis, Cyclotella meneghiniana, Scenedesmus acuminatus var. briseriatus, Euglena acus. At BL6 station in the rainy season, the species of Euglenophyceae densities that were dominant were Euglena acus and Phacus acuminatus, which revealed the mesotrophic to eutrophic conditions of the body of water ${ }^{25}$.

The biomass varied from 5.27-17.09 $\mu \mathrm{g} / \mathrm{L}$ in the dry season and from $3.83-27.31 \mu \mathrm{g} / \mathrm{L}$ in the rainy season (Figure 6). The maximum and minimum biomasses occurred at BL3 and BL9 stations, respectively, in the rainy season. Biomass of Bacillariophyceae was dominant at most sites, which represented the greatest contribution to phytoplankton biomass in the Ba Lai River. The restriction of light entering the environment led to poor growth and development of microalgae because of rich alluvial deposits, which was one of the reasons for the low density and primary biomass of phytoplankton in the shallow and turbid estuary systems. Corresponding to the abundance of phytoplankton, the biomass of cyanobacteria and green algae significant increased at the sites near the Ba Lai dam (where there was actually a marked succession of diatom species) along with the high salinity gradient. The biomass of Bacillariophyceae was high at the other sites. Moving to the upstream sites, the high abundance and biomass of diatoms that adapted to the saline environment were more distributed. This could explain the marine species being carried by the saline flows from the tributaries of the Ba Lai River ${ }^{12}$. This could be a disturbance which greatly explains why the phytoplankton communities were probably influenced by the dam.

\section{Biological indices of phytoplankton commu- nity}

Temporal and spatial variations of phytoplankton metrics are shown in Figure 7.Margalef's diversity in- dex (d) measured density of species in an ecosystem. The higher the index value, the greater the species richness over the study area, and vice versa ${ }^{26}$. Margalef's diversity index (d) ranged from 2.31-6.56 and 2.60-5.36 in the dry and rainy seasons, respectively. The maximum and minimum biomasses occurred in the BL2 and BL8 stations, respectively, in the rainy season. One-way ANOVA was performed and no significant difference of the $\mathrm{d}$ index was detected between the two seasons $(p>0.05)$. The diversity at the sites was relatively high and was evenly increased from the dry season to the rainy season, except for stations BL8 and BL10, of which the dry season is higher than the rainy season. The number of species in both sites was higher in the dry season than in the rainy season, whereas the rest was opposite. Evenness index (J') showed the stability of the phytoplankton communities in the ecosystem, throughout this indicator showed the balance of the community ${ }^{26}$. Evenness index (J') was also high, and $80 \%$ of values surpassed 0.7. The index ranged from 0.62 to 0.89 and from 0.46 to 0.81 in rainy and dry seasons, respectively, and no significant difference of $J$ ' index was detected between the two seasons ( $\mathrm{p}>0.05)$. The BL8 station was lower than the other stations which indicated that the phytoplankton community was dominated by a few species coinciding with the observation of the blooms of Scenedesmus acuminatus var. briseriatus in the study area during both seasons.

\section{Relation of the water temperature to the phytoplankton communities' structure and biodiversity}

The correlation between the water temperature and the phytoplankton communities' structure and biodiversity were evaluated by Spearman's correlation analysis and linear regression analysis. The results of the Spearman's correlation analysis between the water temperature and phytoplankton communities' structure and biodiversity in the rainy season are shown in Table 2. The statistical data was analyzed by Spearman's correlation analysis, which showed that the water temperature positively correlated with chlorophyll-a concentration ( $r=0.793$ ) but negatively correlated with Margalef's diversity index (d) ( $\mathrm{r}=$ 0.711 ) in water. Meanwhile, the other variables did not correlate with the water temperature $(\mathrm{p}>0.05)$; these variables were abundance and biomass of phytoplankton, abundance and biomass of Bacillariophyta, and J' index.

Additionally, the linear regression analysis indicated the relationship between the water temperature and 


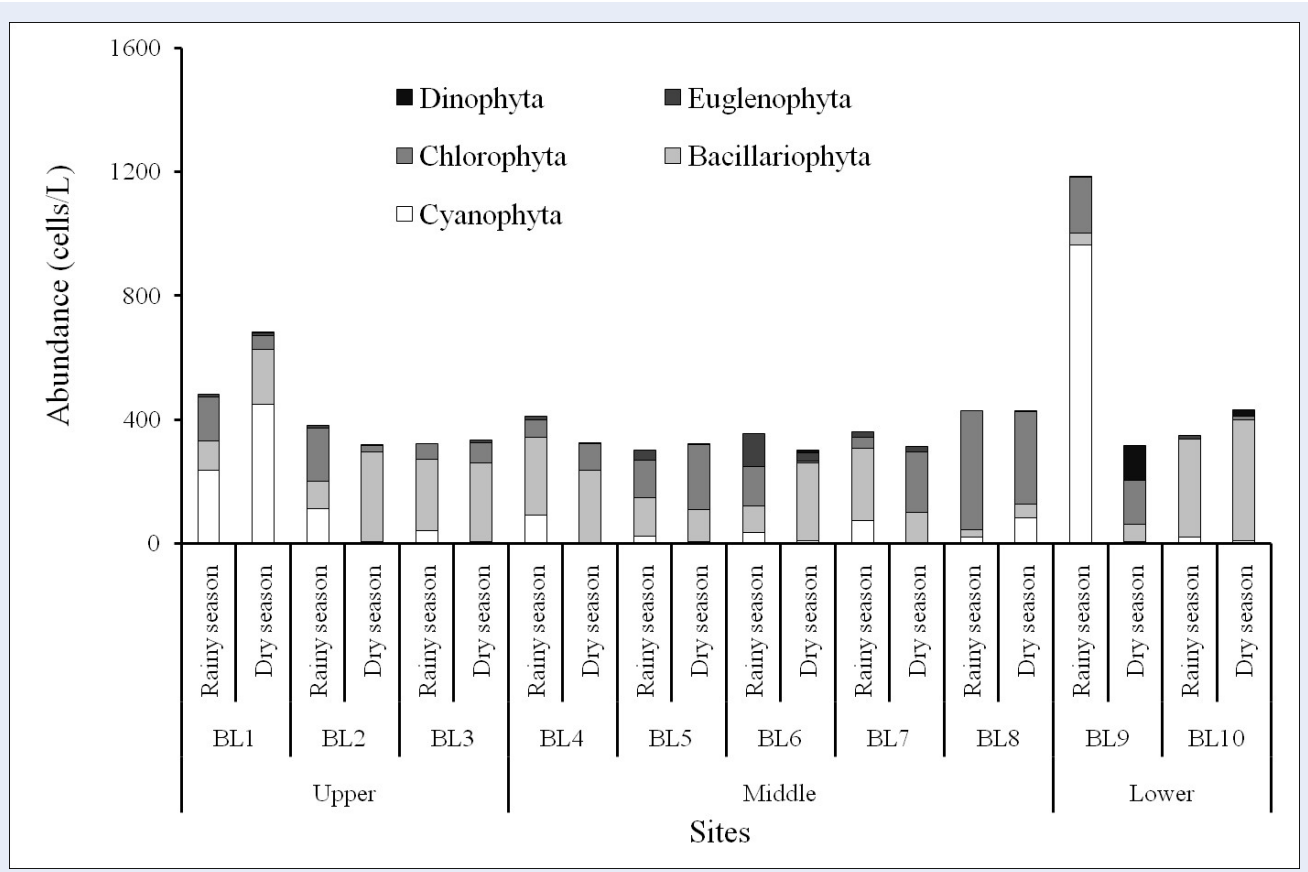

Figure 5: The abundance of phytoplankton in the Ba Lai River.

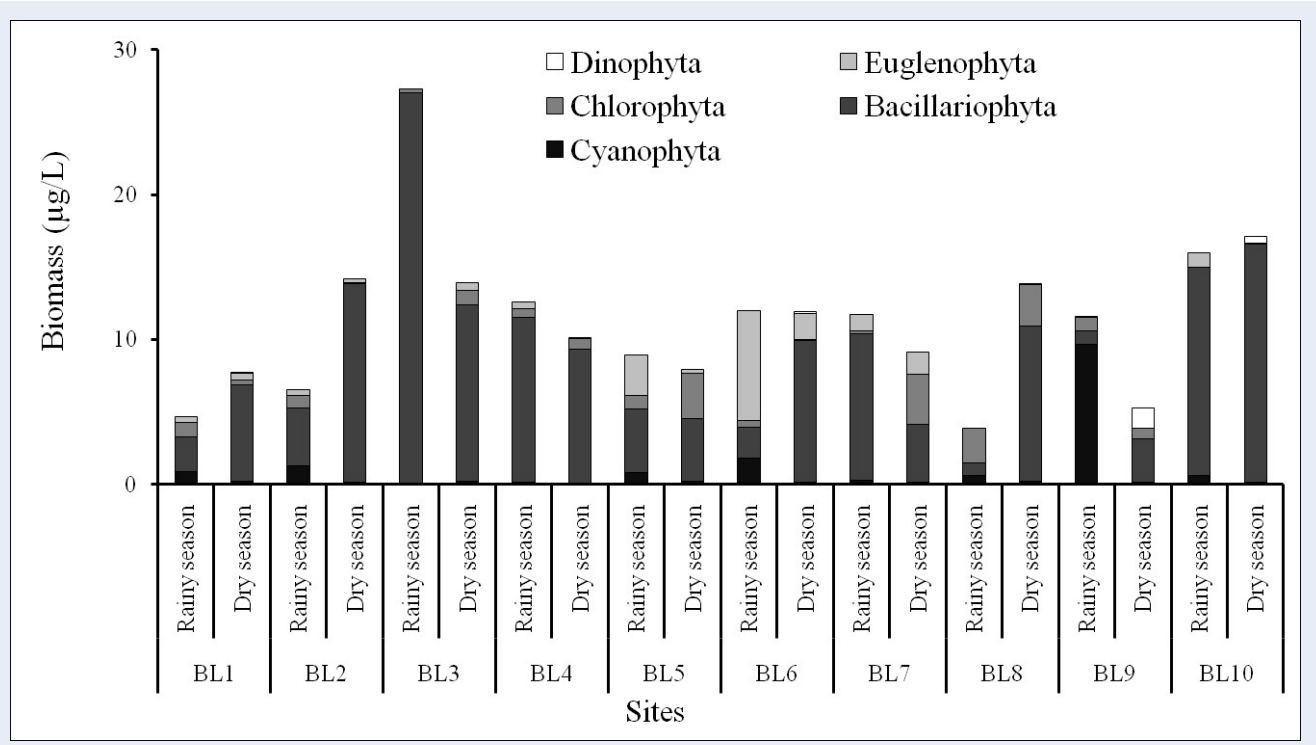

Figure 6: The biomass of phytoplankton in the Ba Lai River. 

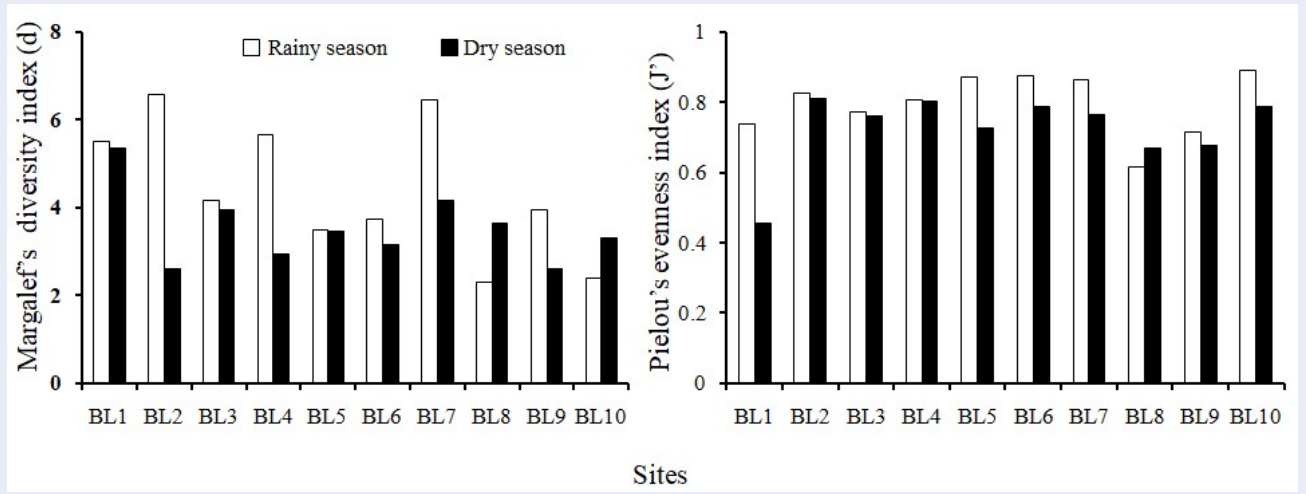

Figure 7: Phytoplankton metrics $\left(d, J^{\prime}\right)$ in the Ba Lai River

Table 2: The correlation coefficient between the water temperature and phytoplankton communities structure, biodiversity in both seasons

\begin{tabular}{|c|c|c|c|}
\hline \multirow[t]{2}{*}{ Variables } & \multicolumn{3}{|c|}{ The water temperature } \\
\hline & & Rainy season & Dry season \\
\hline \multirow[t]{2}{*}{ Abundance of phytoplankton } & $\mathrm{r}$ & -0.024 & -0.711 \\
\hline & $\mathrm{p}$-value & 0.942 & $0.033^{*}$ \\
\hline \multirow[t]{2}{*}{ Abundance of Bacillariophyta } & $\mathrm{r}$ & 0.037 & -0.462 \\
\hline & $\mathrm{p}$-value & 0.913 & 0.166 \\
\hline \multirow[t]{2}{*}{ Biomass of phytoplankton } & $\mathrm{r}$ & 0.11 & -0.742 \\
\hline & $\mathrm{p}$-value & 0.743 & $0.026^{*}$ \\
\hline \multirow[t]{2}{*}{ Biomass of Bacillariophyta } & $\mathrm{r}$ & -0.529 & -0.790 \\
\hline & $\mathrm{p}$-value & 0.112 & $0.018^{*}$ \\
\hline \multirow[t]{2}{*}{ Chlorophyll-a concentration } & $\mathrm{r}$ & 0.793 & 0.376 \\
\hline & $\mathrm{p}$-value & $0.017^{*}$ & 0.259 \\
\hline \multirow[t]{2}{*}{$\mathrm{d}$ index } & $\mathrm{r}$ & -0.711 & -0.363 \\
\hline & p-value & $0.033^{*}$ & 0.276 \\
\hline \multirow[t]{2}{*}{$J$ 'index } & $\mathrm{r}$ & 0.103 & 0.007 \\
\hline & $\mathrm{p}$-value & 0.757 & 0.985 \\
\hline
\end{tabular}

Note: ${ }^{*}$ Correlation is significant at the 0.05 level

chlorophyll-a concentration, and d index, as illustrated in Figure 8. The water temperature had a positive correlation with chlorophyll-a concentration, using a relatively low adjusted coefficient of simple linear regression model (adjusted $\mathrm{R}^{2}=43.787 \%$, $\mathrm{p}=0.022$ ). Meanwhile, the water temperature was significantly and negatively correlated with $\mathrm{d}$ Index and a substantially predictive capability $\left(\mathrm{R}^{2}=49.599 \%\right.$, $\mathrm{p}=0.014$ ).

Furthermore, the results of stepwise multiple linear regression analysis showed that when combining the concentration of chlorophyll-a and the d Index, the relationship between water temperature and the two factors could be interpreted in a highly significant model. The observed versus predicted water temperatures in the Ba Lai River are shown in Figure 9. That is, the water temperature positively correlated with concentration of chlorophyll-a but had a negative relationship with $\mathrm{d}$ Index.

Water temperature $=1.5602+0.0232414 \times$ Chlorophyll-a $-0.103903 \times \mathrm{d}$ Index

(with: $\mathrm{R}^{2}=71.74 \%, \mathrm{p}=0.005$ ) 

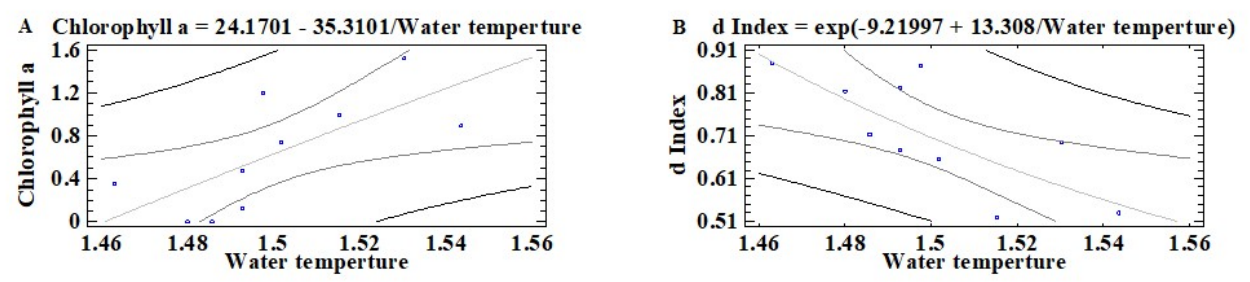

Figure 8: Model of linear regression analysis in the rainy season. A. The correlation between water temperature and chlorophyll-a concentration, B. The correlation between water temperature and $\mathrm{d}$ Index.

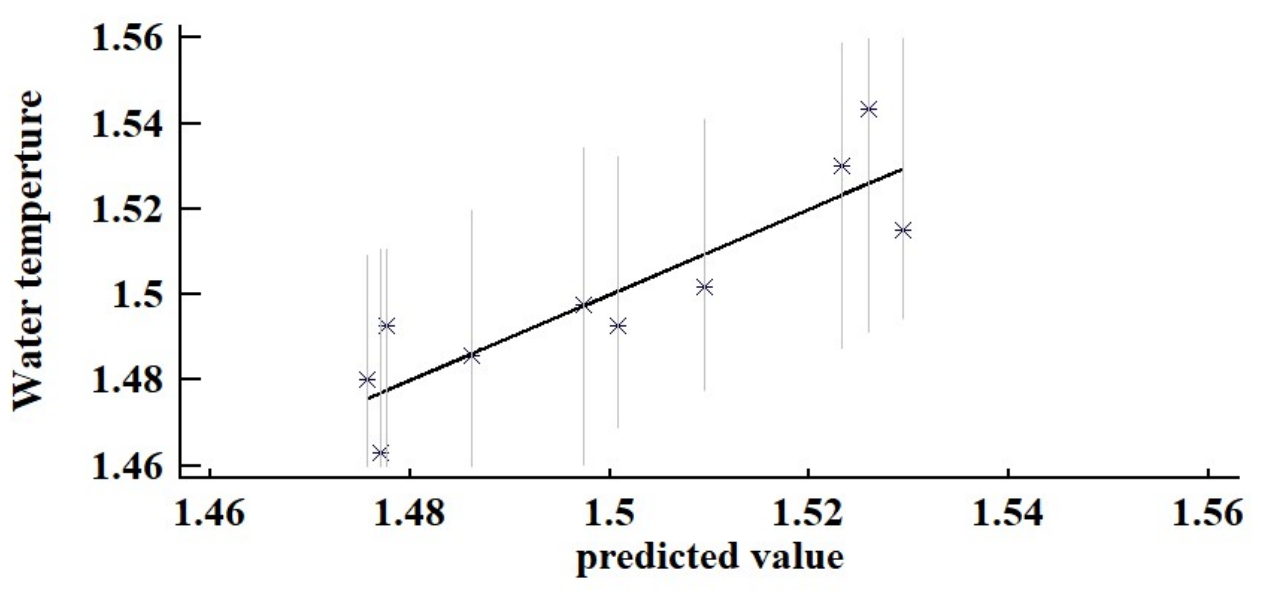

Figure 9: The observed versus predicted water temperatures in the Ba Lai River.

The results of the Spearman's correlation analysis on water temperature and phytoplankton communities' structure, and biodiversity in the dry season indicated that the water temperature negatively correlated with abundance of phytoplankton, biomass of phytoplankton and biomass of Bacillariophyta (Table 2) ( $\mathrm{r}=$ $0.711, r=-0.742, r=-0.790$, respectively). Meanwhile correlations of the water temperature with the other variables were non-significant. Furthermore, the simple linear regression between the water temperature and biomass of phytoplankton, and biomass of Bacillariophyta (excepted abundance of phytoplankton) resulted, actually, in a model with a substantially higher predictive capability (Figure 10). In this model, the water temperature had a significant negative correlation with biomass; the biomass of Bacillariophyta were able to yield two models with substantially and relatively low predictive capability (adjusted $\mathrm{R}^{2}=46.37 \%, \mathrm{p}=0.018 ; \mathrm{R}^{2}=47.21 \%, \mathrm{p}=0.017$, respectively).

\section{DISCUSSION}

Phytoplankton reflect and affect water quality which changes in its community structure, patterns of distribution and the proportion of sensitive species. In our study, the phytoplankton assemblages in the $\mathrm{Ba}$ Lai River included freshwater, estuarine and freshwater, and estuarine and marine species (which were dominated by diatoms). The dominance of this group (diatoms) has been already reported by other authors either along the river or estuary; however, studying in running water conditions are more appropriate for evaluating growth of diatoms ${ }^{8,27,28}$. Generally, dominance of diatoms indicates the physical inconsistency of the shallow coastal environments which are very common to study; most diatoms are robust and remain in the estuarine environments in spite of the erratic salinities ${ }^{29,30}$.

Biodiversity is an important component of ecosystem functioning and stability and it has been widely used to characterize community structure. The diversity of 

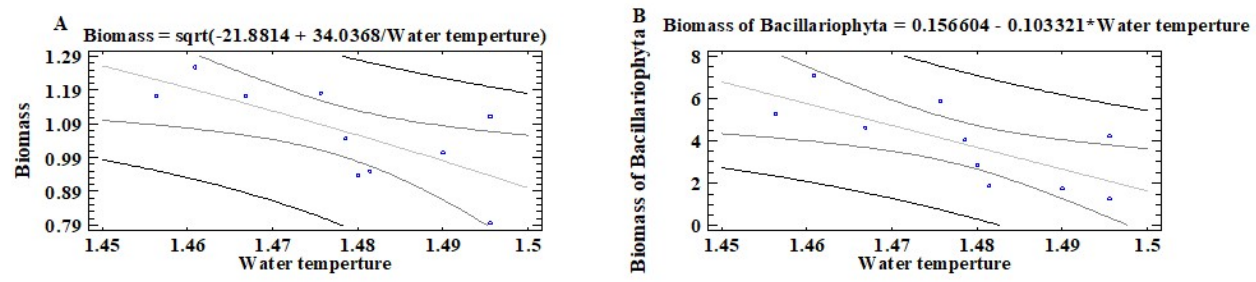

Figure 10: Model of Linear regression analysis in dry season. A. The correlation between water temperature and biomass, B. The correlation between water temperature and biomass of Bacillariophyta.

a community depends on the Species Richness and Species Evenness ${ }^{31,32}$. The Margalef's Diversity Index and Evenness Index were relatively high, which explains that the evenness between the survey sites reflects the uniformity and stability of ecological characteristics in the area. However, there were many clear evidences that the Ba Lai dam caused many negative effects on phytoplankton community and biodiversity in the river.

The environmental parameters influence the phytoplankton distribution; of these parameters, water temperature plays a fundamental role and induces marked changes in a community structure. In the rainy season, the water temperature had a positive relationship with chlorophyll-a concentration but negative correlation with $d$ Index. That means if the water temperature increased, chlorophyll-a content increased. However, while there was an increase in water temperature, the $\mathrm{d}$ Index decreased, and vice versa. Chlorophyll-a concentration is a convenient index of phytoplankton biomass, and water temperature is an important factor which influences the control of the growth and distribution of phytoplankton ${ }^{32-34}$.

In the aquatic ecosystem, chlorophyll-a concentration usually is recognized as a surrogate for biomass of phytoplankton which is dependent primarily on several environmental parameters and has been studied in recent studies ${ }^{35}$. According to the study in Meiliang Bay (China), the concentration of chlorophyll-a was significantly correlated with water temperature; a multiple stepwise linear regression explained 99.2\% of the variation of chlorophyll-a. However, in Taihu Lake (China), the water temperature explained 98.7\% of the variation of chlorophyll-a.

Thus, water temperature is an important factor influencing the annual change of chlorophyll-a concentration and phytoplankton biomass ${ }^{36}$. In general, biodiversity is an important factor which determines phytoplankton community performance under varying temperature conditions ${ }^{6}$. Biodiversity is a useful alternative to reflect the ecological quality of aquatic ecosystems because biological communities are influenced and integrated by the environmental effects of water ${ }^{37}$. The warmth of the water temperature and environmental instability caused changes in phytoplankton diversity and community structure, which are indispensable characteristics underlying ecosystem functioning and trophic transfer ${ }^{38}$. From the research in Vam Co River (Vietnam), the phytoplankton biodiversity positively correlated with water temperature and species number ${ }^{39}$. Moreover, when combining the concentrations of chlorophyll-a and d Index, the highly significant model of water temperature was predicted (Figure 9). Increasing the concentration of chlorophyll-a will lead to rise of water temperature but it is limited by the diversity index. Likewise, in the dry season, the water temperature had a significant negative correlation with biomass and the biomass of Bacillariophyta found in this study. That means, if the water temperature increased, the biomass of phytoplankton and biomass of Bacillariophyta decreased, and vice versa. The impact of temperature on phytoplankton entails nutrient uptake, death rate, and nutrient release from particulate nutrients, abundance, and biomass; all of these parameters were investigated by recent studies. The effects of seasonal temperature and daily temperature on phytoplankton biomass were simulated numerically and showed that the phytoplankton biomass was strong to the effects (and variation) of water temperatures, according to the dynamics of the model and model predictions in Lake Tai (China) ${ }^{38}$. Changes in phytoplankton biomass and photosynthesis in relation to temperature were showed in the Western English Channel ${ }^{40}$. Dinoflagellates and biomass showed a positive correlation with respect to temperature, reaching the highest biomass (between $15^{\circ} \mathrm{C}$ and $17^{\circ} \mathrm{C}$ ). On the other hand, diatoms indicated a negative correlation with temperature, with highest biomass at $10^{\circ} \mathrm{C}^{41}$. 
Besides the other abiotic variables, the variability of water temperature can be considered a major factor contributing to the changes of the phytoplankton community structure, which was favorable for the development of chlorophyll-a concentration, diversity index and biomass. According to the studies in the Ba Lai River, there were more factors influencing phytoplankton growth. For instance, the phytoplankton assemblage was affected by total dissolved solids, salinity and nutrients. This indicates that in addition to nutrient concentrations, the total dissolved solids significantly influence the phytoplankton community structure as a result of high turbidity affected by tides and silt accretion in the estuary ${ }^{12}$. Thus, predictive models for relationships between water temperature and phytoplankton community structure are preliminary data which can provide baseline information and be used as critical ecological tools for water quality management.

\section{CONCLUSION}

Results of this study contributed the advantageous information on phytoplankton structure and diversity, as well as their correlation with water temperature in running water systems which are becoming more and more popular in Vietnam. The phytoplankton assemblage in the Ba Lai River was typical in the shallow and turbid estuarine systems where diatoms were clearly dominant in both the dry and rainy seasons. Additionally, the results illustrated that the temperatures of surface water from the Ba Lai River did not vary among the sampling sites and was similar to the water temperature of some other rivers in Southern Vietnam, which were beneficial for the development of phytoplankton. The relationships showed that rises in water temperature could significantly elevate the chlorophyll-a concentration but decrease the diversity index, biomass of phytoplankton, and biomass of diatoms (which were the primary species in terms of species number). Water temperature is one of the key factors that changes phytoplankton distribution and associates with phytoplankton bloom, in turn influencing the whole food chain and which can seriously impact future global warming. Therefore, it is essential to observe how the changes of environmental parameters impact phytoplankton assemblages in river ecosystems so that the water supply issues in the region can be effectively managed.

\section{COMPETING INTERESTS}

The authors declare that there is no conflict of interest regarding the publication of this article.

\section{AUTHORS' CONTRIBUTIONS}

The contributions of all authors are equal in selecting data, calculating descriptors, analyzing results, and writing a manuscript.

\section{ACKNOWLEDGMENTS}

This research was funded by Vietnam National Foundation for Science and Technology Development (NAFOSTED) under grant number 106.06-2019.51.

\section{REFERENCES}

1. Marañón E, Lorenzo MP, Cermeño $P$, Mouriño-Carballido B. Nutrient limitation suppresses the temperature dependence of phytoplankton metabolic rates. The ISME journal. 2018;12(7):1836. PMID: 29695860. Available from: https: //doi.org/10.1038/s41396-018-0105-1.

2. Padisak J, Borics G, Grigorszky I, Soróczki-Pintér E. Use of phytoplankton assemblages for monitoring ecological status of lakes within the Water Framework Directive: the assemblage index. Hydrobiologia. 2006;553(1):1-14. Available from: https://doi.org/10.1007/s10750-005-1393-9.

3. Ye YY, Luo Y, Wang Y, Lin M, Xiang P, Ashraf MA. Relation between diversity of phytoplankton and environmental factors in waters around nanri island. Applied ecology and environmental research. 2017;15(3):241-252. Available from: https://doi.org/10.15666/aeer/1503_241252.

4. Torremorell A, Llames ME, Perez GL, Escaray R, Bustingorry J, Zagarese $\mathrm{H}$. Annual patterns of phytoplankton density and primary production in a large, shallow lake: the central role of light. Freshwater Biology. 2009;54(3):437-449. Available from: https://doi.org/10.1111/j.1365-2427.2008.02119.x.

5. Saifullah ASM, Kamal AHM, Idris MH, Rajaee AH. Community composition and diversity of phytoplankton in relation to environmental variables and seasonality in a tropical mangrove estuary. Regional Studies in Marine Science. 2019;32:100826. Available from: https://doi.org/10.1016/j.rsma.2019.100826.

6. Schabhüttl $S$, Hingsamer $P$, Weigelhofer $G$, Hein T, Weigert A, Striebel M. Temperature and species richness effects in phytoplankton communities. Oecologia. 2013;171(2):527536. PMID: 22847329. Available from: https://doi.org/10.1007/ s00442-012-2419-4.

7. Striebel $M$, Schabhüttl S, Hodapp $D$, Hingsamer $P$, Hillebrand $\mathrm{H}$. Phytoplankton responses to temperature increases are constrained by abiotic conditions and community composition. Oecologia. 2016;182(3):815-827. PMID: 27488200. Available from: https://doi.org/10.1007/s00442-016-3693-3.

8. Brogueira MJ, Rosário-Oliveira M, Cabeçadas G. Phytoplankton community structure defined by key environmental variables in Tagus estuary, Portugal. Marine environmental research. 2007;64(5):616-628. PMID: 17884159. Available from: https://doi.org/10.1016/j.marenvres.2007.06.007.

9. Yang C, Nan J, Li J. Driving Factors and Dynamics of Phytoplankton Community and Functional Groups in an Estuary Reservoir in the Yangtze River, China. Water. 2019;11(6):1184. Available from: https://doi.org/10.3390/w11061184.

10. Ngo QX, Sayenko EM, Lutaenko KA. Bivalves composition and ecological aspects of the Ba Lai River, an estuary of the Mekong Delta, Vietnam. The Korean Journal of Malacology. 2018;34(3):169-178. Available from: https://doi.org/10.9710/ kjm.2018.34.3.169.

11. Nguyen TS, Nguyen MH. Study on deposition of Ba Lai estuary, Ben Tre province. Journal of Science. 2011;27(1):211-217.

12. Pham TL, Tran TND, Tran TT, Nguyen TMY, Ngo XQ. Seasonal variations of phytoplankton community structure in relation to physico-chemical factors in Ba Lai river, Ben Tre Province. Vietnam Journal of Agricultural Sciences. 2017a;15(5):631641. 
13. Bartram J, Chorus I. Toxic cyanobacteria in water: A guide to their public health consequences, monitoring and management. Published on behalf of WHO, Spon Press London. 1999;416. Available from: https://doi.org/10.1201/ 9781482295061 .

14. Shirota A. The plankton of South Vietnam-Fresh water and marine plankton. Overseas Technical Cooperation Agency Japan. 1966;.

15. Wehr JD. Freshwater algae: identification and use as bioindicators. Journal of Phycology. 2011;47(2):436-438. Available from: https://doi.org/10.1111/j.1529-8817.2011.00973.x.

16. Edward GB, David CS. Freshwater algae: identification, enumeration and use as bioindicators. 2nd Edition. WileyBlackwell. 2015;.

17. Guiry DM, Guiry MG. AlgaeBase. World-wide electronic publication, National University of Ireland, Galway. 2014;Available from: http://www.algaebase.org.

18. Sournia A. Phytoplankton manual, published by UNESCO. 1978;.

19. Sun J, Liu D. Geometric models for calculating cell biovolume and surface area for phytoplankton. Journal of plankton research. 2003;25(11):1331-1346. Available from: https: //doi.org/10.1093/plankt/fbg096.

20. Wetzel RG, Likens GE. Limnological analyses. Springer Science \& Business Media. 2013;

21. Uttah EC, Uttah C, Akpa PA, Ikpeme EM, Ogbeche J, Usip L, et al. Bio-survey of plankton as indicators of water quality for recreational activities in Calabar River, Nigeria. Journal of Applied Sciences and Environmental Management. 2008;12(2):35-42. Available from: https://doi.org/10.4314/ jasem.v12i2.55525.

22. Dao TS. Relationship between Phytoplankton and Environmental Variables from Bien Ho and Lak Lakes in Central Highland of Vietnam. Journal of Environment and Ecology. 2016;7(2). Available from: https://doi.org/10.5296/jee.v7i2. 9704 .

23. Wetzel RG. Limnology: lake and river ecosystems (3rd edition). Academic Press San Diego. 2001;p. 205-288-331-393.

24. Miao X, Wang S, Liu M, Ma J, Hu J, Li T, et al. Changes in the phytoplankton community structure of the Backshore Wetland of Expo Garden, Shanghai from 2009 to 2010. Aquaculture and Fisheries. 2019;4(5):198-204. Available from: https: //doi.org/10.1016/j.aaf.2019.02.004.

25. Palmer CM. A composite rating of algae tolerating organic pollution 2. Journal of Phycology. 1969;5(1):78-82. PMID: 27097257. Available from: https://doi.org/10.1111/j.15298817.1969.tb02581.x.

26. Magurran AE. Ecological diversity and its measurement. Princeton university press. 1988;p. 175. Available from: https: //doi.org/10.1007/978-94-015-7358-0.

27. Pham TL, Tran THY, Tran TT, Ngo XQ. Relationship Between Phytoplankton Community And Environmental Variables In The Ham Luong River, Ben Tre Province, Vietnam. Journal of Marine Science and Technology. 2017b;17(4A):235-245.

28. Duong TT, et al. Seasonal variation of cyanobacteria and $\mathrm{mi}-$ crocystins in the Nui Coc Reservoir, Northern Vietnam. Journal of Applied Phycology. 2013;25:1065-1075. Available from: https://doi.org/10.1007/s10811-012-9919-9.

29. Fernandez LF, Brandini FP. Diatom association in variation in shelf waters off Parana State, Southern Brazil: Annual variation in relation to environmental factors. Brazilian J Oceanogr.
2004;52:19-34. Available from: https://doi.org/10.1590/S167987592004000100003

30. Pouladi M, Qadermarzi A, Baharvand F, Vazirizadeh A, Hedayat A. Effects of physicochemical factors on seasonal variations of phytoplankton in the Mond River Estuary of Bushehr Province, Persian Gulf, Iran. Biodiversitas Journal of Biological Diversity. 2017;18(1). Available from: https://doi.org/10.13057/biodiv/ d180130.

31. Cardinale BJ, et al. Biodiversity loss and its impact on humanity. Nature. 2012;486(7401):59. PMID: 22678280. Available from: https://doi.org/10.1038/nature11148.

32. Ekhator O, Alika F. Phytoplankton diversity indices of Osse river, Edo state, Nigeria. Ife Journal of Science. 2016;18(1):6384.

33. Lerdburoos $\mathrm{Y}$, Tarnchalanukit $\mathrm{W}$, Tabthipwon $\mathrm{P}$, Yoonphand R. Relationship among Nutrients, Chlorophyll-a, Physical and Chemical Properties of Water in Srinadharin Reservoir, Kanchanaburi Province. Naresuan University Journal: Science and Technology (NUJST). 2013;18(2):9-16

34. Nurdin S, Mustapha MA, Lihan T. The relationship between sea surface temperature and chlorophyll-a concentration in fisheries aggregation area in the archipelagic waters of Spermonde using satellite images. In AIP Conference Proceedings. 2013;1571(1):466-472. Available from: https://doi.org/ $10.1063 / 1.4858699$.

35. Baliarsingh SK, Lotliker AA, Sahu KC, Kumar TS. Spatiotemporal distribution of chlorophyll-a in relation to physicochemical parameters in coastal waters of the northwestern Bay of Bengal. Environmental monitoring and assessment. 2015;187(7):481. PMID: 26130242. Available from: https: //doi.org/10.1007/s10661-015-4660-x.

36. Cai LL, Zhu GW, Zhu MY, Xu H, Qin BQ. Effects of temperature and nutrients on phytoplankton biomass during bloom seasons in Taihu Lake. Water science and engineering. 2012;5(4):361-374.

37. Adelakun KM, Mu'azu MM, Amali RP, Omotayo OL. Diversity of Phytoplankton Communities in a Tropical River Basin, Nigeria. Hydro Nepal: Journal of Water, Energy \& Environment. 2016;19:52-56. Available from: https://doi.org/10.3126/ hn.v19i0.15353.

38. Rasconi S, Winter K, Kainz MJ. Temperature increase and fluctuation induce phytoplankton biodiversity loss-Evidence from a multi-seasonal mesocosm experiment. Ecology and Evolution. 2017;7(9):2936-2946. PMID: 28479993. Available from: https://doi.org/10.1002/ece3.2889.

39. Dao TS, Bui TNP. Phytoplankton from Vam Co River in Southern Vietnam. Environmental Management and Sustainable Development. 2016;5(1):113-125. Available from: https://doi. org/10.5296/emsd.v5i1.8775.

40. Chen M, Fan M, Yuan X, Zhu H. Effect of seasonal changing temperature on the growth of phytoplankton. Mathematical Biosciences \& Engineering. 2017;14(5\&6):1091-1117. PMID: 29161852. Available from: https://doi.org/10.3934/mbe. 2017057.

41. Xie $\mathrm{Y}$, Tilstone $\mathrm{GH}$, Widdicombe $\mathrm{C}$, Woodward EMS, Harris $\mathrm{C}$ Barnes MK. Effect of increases in temperature and nutrients on phytoplankton community structure and photosynthesis in the western English Channel. Marine Ecology Progress Series. 2015;519:61-73. Available from: https://doi.org/10.3354/ meps11101. 